ARTICLE

DOI: $10.1057 /$ s41599-018-0115-7

\title{
The politics of the China__Pakistan economic corridor
}

Maham Hameed ${ }^{1}$

ABSTRACT China's presence in the Global South has increased dramatically over the course of a decade. The discourse of mutual benefit and non-intervention has attracted much attention in the developing world, which is now facing the consequences of Western interventions. However, the extent to which Chinese engagement in the developing world stays true to these principles needs to be evaluated in terms of its effects on the political economic structures of the host nations. This study analyses how China and the China-Pakistan Economic Corridor (CPEC) is interacting with the political and economic realities of Pakistan. Firstly, the study traces the history of regionalism in Pakistan and shows that over the years, the developmental mission of the central state has created deep-seated regionalism in Pakistan. The study shows that CPEC is deepening such cleavages. The regionalist forces have opposed the project in two broad ways: through demanding a greater share in the project or through completely rejecting the interventions. Secondly, the study analyses the lop-sided civil-military relations in Pakistan and concludes that Chinese engagement in Pakistan is leading to the military's tighter control of civilian and economic matters relating to CPEC.

\footnotetext{
${ }^{1}$ Graduate Institute of Development Studies, Lahore, Pakistan. Correspondence and requests for materials should be addressed to M.H. (email: maham.hameed91@gmail.com)
} 


\section{Introduction}

hina's global rise has been presented in sharp contrast to the Western global order. The discourse of mutual benefit and non-interference has been maintained by not just China but also the countries that it engages with. A similar discourse has been deployed in Pakistan. However, discrepancies to these promises and hopes have not been hard to spot. In order to fully understand the implications of the Chinese presence in the third world, particularly in Pakistan, I look at the effects of Chinese engagement on the political economic structure of Pakistan. An analysis of Pakistan's political economic structure, Pakistan's history of infrastructure development, China's foreign policy and national interests, and the basis of Pakistan-China friendship is utilized to understand how the China-Pakistan Economic Corridor (CPEC) is interacting and is expected to interact with the state structure of Pakistan.

\section{CPEC and the strategic interests}

Before we begin to understand the possible implications of Chinese engagement in Pakistan, personified by the CPEC, it is important to understand what the project means for both the states. An understanding of the strategic importance of the project and how the project interacts with the historical interests of both nations will better equip us to analyze the CPEC in terms of its political and social impacts.

Pakistan Muslim League (N) ${ }^{1}$ assumed office in 2013 after its sweeping victory in the general elections 2013 of the National Assembly. The regime, led by two main protagonists-the Sharif brothers-was all about the economy: the Sharif's had sold its vote bank the dream of a prosperous economy backed by a strong infrastructure network (Small, 2015). All the ambitious plans of motorways, industrial zones, and fixing energy crisis could not be financed locally and the Sharif government knew where to look for the investments. During this time, China, rethinking its economic policy that had sustained China's growth for over three decades, was ambitiously looking to build an integrated South Asian infrastructure to connect interior China to the ports of Indian Ocean. The infrastructural investments had become prerequisite for maintaining high growth rates in the newly growing provinces of Yunnan and Xinjiang. China looked for collaboration from India and Pakistan. Li Keqiang-the Chinese Prime Minister - first visited India with his ambitious proposals. However, India found its economic ally in Japan instead. Next was Pakistan's turn.

However, convincing China to invest in Pakistan would not be an easy task for the Sharif government. Many of Chinese initiatives had languished in the past due to the incumbent regime's lack of political will (Small, 2015). However, the Pakistani government's commitment was to ease these qualms for China. Li arrived Pakistan on 22nd May, 2013 with an ambitious proposal of regional connectivity and resolution of Pakistan's energy crisis. Pakistani civil and military leadership welcomed $\mathrm{Li}$ with grand gestures. From here on, the Xinjiang-Gwadar connection idea picked up pace. China was also willing to help Pakistan alleviate its energy crisis through building hydro-electric dams, coal-fired power stations, and nuclear power plants. Ideas were being quickly materialized: plans were made, meetings were held, and Memorandum of Understanding (MOUs) were signed.

However, not all was smooth sailing. China would soon have to reconsider its plans in Pakistan following terrorist attacks either targeting CPEC workers or the proposed regions for CPEC projects. ${ }^{2}$ Chinese suspicions were received with promises of commitment by the Sharif government to make the execution of the corridor smooth and safe. China decided to tread carefullystarting with smaller projects.
Pakistan was to soon prove central to Beijing's concerns, dispensing all qualms China had about investing in Pakistan. A bomb attack in Tiananmen Square, Beijing on 28th October 2013, for which the Turkistan Islamist Party ${ }^{3}$ claimed responsibility, was a wake-up call for China. This attack was followed by knife and bomb attack in Kunming and Urumqi railway stations indicating the spread of terrorism from the country's remote northwest to its urban centers (Small, 2015). If the 2009 riots between Han Chinese and the Muslim Uighurs in Xinjiang were not enough, this series of incidents shook up Beijing to pay closer attention to Pakistan and Afghanistan (Pant, 2012). Stability in these countries was to be of great concern to China lest the Islamist extremism spread in the Western region of China (Pant, 2012). Hence, Pakistan is crucial to China's economic interests and its desire to expand its influence in the region. Although it did not change anything for the major economic projects in the pipeline (in fact, Li's next visit and the near-final plans of the major projects were to show that they had become even more critical for Chinese interests), China began to put pressure on the security establishment in Pakistan for a crackdown on the Uighur militants ${ }^{4}$ in North Waziristan (Small, 2015). The political infighting between the civilian government and military establishment led to embarrassing delays in reaching an agreement. However, despite their differences, one thing that the Pakistani leadership agreed on was the value of Pak-China friendship, which now promised an influx of $\$ 46$ billion that would transform the Pakistani economy. As the pressure from the Chinese government intensified, Raheel Sharif finally obliged and launched an operation in North Waziristan. However, the decision to deploy tens of thousands of troops in the region was triggered by other factors pertaining to terrorism and security situation in the country too (Small, 2015).

Although security concerns are an important factor explaining China's interest in Pakistan, China has other reasons to strengthen its ties with Pakistan too. In the last two decades, China has increased its global presence. To this end, China is taking a more proactive role in creating diplomatic ties with other nations. Pakistan is among the few countries that China can call a friend (Shambaugh, 2013). The friendship is a welcome change for the Pakistani political elites and various institutions of the state that are experiencing increasingly deteriorating relationship with the US (Small, 2015). Public support for Pak-China relations in Pakistan is also striking (Chandra, 2016). According to the Pew Research Centre survey of public opinion about China in Pakistan, 84 per cent of the respondents held a positive view about China, compared to 16 per cent for the US. If the survey is a realistic representation of reality, then Pakistan might be the most pro-China country in the world (Chandra, 2016).

The impetus that China-Pakistan friendship quickly gained post-2010 cannot be sufficiently explained by the Chinese interests in Pakistan alone. Pakistan had strong motivations behind strengthening its ties with China too. Pakistani military and civilian government had recently lost its long-standing friendthe US-and was experiencing the economic and military vacuum left behind by the US withdrawal.

Since its foundation, Pakistan has been highly dependent on foreign aid. One of its biggest donors throughout the history of the nation has been the United States. The flow of aid started as a part of the economic reconstruction effort. The aid played a crucial role in the high growth rates achieved in the 1960s-it gave impetus to industrialization and helped combat food insecurity (Zaidi, 2004, p. 104). The inflow of foreign aid during this period also lent support to public investment in infrastructure (mostly in power and irrigation sectors), and social services (Khan and Ahmed, 2007, p. 220). 
Later, the ideological alignment and military ties with the US during the Cold War accelerated the flow of aid and irreversibly tied the Pakistani military into the foreign aid and development nexus (Zaidi 2004, p. 104). The aid accelerated during the Soviet occupation of Afghanistan when the US lent its financial and military support to Pakistan to fight the Afghan War (Cooley, 2001). Since, the funds and training were not to be provided directly through the Central Intelligence Agency, but through Pakistan and its army, the security establishment accumulated immense power during this period (Cooley, 2001). Although aid during this period assisted Pakistan in upgrading its defense forces and military technology, it did so at the cost of rising terrorism, sectarianism, refugee crisis, rising debt-servicing expenses, and falling GDP (Hilali, 2002).

US-Pakistan relations remained strained throughout the 1990s; however, the friendship attained a new meaning following United States' War on Terror. Pakistan received aid packages to fight terrorism within and outside its borders (Qazi, 2012). The political and social impact of war on terror within Pakistan has been disastrous. ${ }^{5}$ Furthermore, Pakistan's security establishment that has consistently provided refuge to the Taliban due its strategic interests, refused to comply with the US demands (Qazi, 2012). Civilian government too has been put off by the increasingly chaotic nature of the aid. Disappointed by Pakistan's performance in fighting terrorism, the US keeps announcing delays or cancellation of the promised aid (Naviwala, 2017). In consequence, Pakistan has experienced a gradual withdrawal of the US resulting from the doubts that the US policy makers have cast upon the Pakistan's role in fighting terrorism and effectiveness of aid as a counter-terrorism policy (Zaidi, 2011).

Following the US raid that killed Osama bin Laden in 2011, Pakistan faced intense international condemnation regarding its role in fighting extremism within its boundaries. During such times the country that openly voiced support for Pakistan was China (Pant, 2012). China expressed its interest in becoming an "all-weather strategic partner" of Pakistan (Pant, 2012). It was in this backdrop that the developmental vision of the Sharif government, the political and economic interests of the military establishment, and global, national and strategic interests of the Chinese government coincided.

All these interests converged and manifested in the form of CPEC.

\section{CPEC as state-space}

One of the most prominent features of CPEC is the highly visible presence of state. Both Chinese and Pakistani states have precious stakes in the project and are playing a crucial role in kick-starting the investment regime constituting both public and private sectors. Pakistani state, specifically the Sharif government, is at pains to claim ownership of the project despite the fact that allegedly most of the projects will be private ventures. The signing of MoUs, financial agreements, inauguration ceremonies, and press releases are heavily advertised through media. On project sites, along with a billboard of President Xi Jinping's picture, Prime Minister Nawaz Sharif s picture is carefully placed. Quick results of CPEC will bode well for PML-N in the next elections, but the relationship between the state and infrastructure is much deeper than interests of one regime. State and infrastructure are closely entwined together in the exercise of nation-making. In the following sections, I briefly review the literature on the relationship between infrastructure and state. To better understand the relationship between state and infrastructure in the case of Pakistan, I deconstruct the Pakistani state into the central state, regional elites and military and analyse the role of these power groups in the development of infrastructure in Pakistan.

\section{Infrastructure as state-space}

Infrastructures are matters that enable the movement of other matter (Larkin, 2013 p. 328). Very broadly, infrastructure is a physical and institutional structure that facilitates the flow of people, commodities, ideas and information (Guldi, 2012; Larkin, 2013). Although infrastructure in various forms have existed for millennia, the intersection of economic requirements, technical expertize and political incentives to create standardized structures for the purpose of consolidating state power and integrating nation is a modern phenomenon (Knox and Harvey, 2012, p. 523). In other words, infrastructure is increasingly understood as a means to gain legitimacy; to create an 'integrated' national space and ideology (Anwar, 2015; Goswami, 2004; Akhter, 2015; Knox and Harvey, 2012, 2015).

Marx in reflecting on the link between provision of infrastructure (what he termed as public works) and capital accumulation, argued that only in the most advanced stage of capitalism can capital itself provide the "the general condition of production" (1857-61). Until then, the capital appoints the task of providing infrastructure to the state. Alternately, the state still enjoys the authority and drive to make the society pay for the infrastructure in form of revenues (Marx, 1857-).

Henri Lefebvre refined the Marxist understanding of the connection between capitalist state and infrastructure by theorizing relationship between state and space (Lefebvre, 2009, p. 223; Akhter, 2015, p. 852). Apart from providing infrastructure to facilitate capital, he argued that state has a deeper relationship with space. For him, "homogenized, hierarchized, and fragmented spaces" are produced through capital but also crucially through the spatial strategies (including institutional and material innovations and scientific knowledge) of the state (Lefebvre, 2009). The aim is to extend the political and social outreach and to fully penetrate the society.

This is an important point in relation to infrastructure and is worth delving into further. Manu Goswami in his study of production of colonial space in India argues infrastructure became a tool for the colonial government to lend legitimacy to the narrative that British rulers were there to help India progress and to integrate the state-space through new rules of subjectivity ${ }^{6}$ (2004). Similarly, writing about a cross-border highway in Albania and Greece, Dimitris Dalakoglou, analyses how infrastructures reflects the fetishistic desires of the planning authorities to participate in the conceptual and visual pattern of modernity as imagined by advanced nations (Dalakoglou, 2010). Morten Alex Pedersen makes a similar point about Russian investment into infrastructure as a precondition to socialist modernity (Larkin, 2013, p. 333). Infrastructure development was planned not only as serving economic purposes but it was imagined as "investing in a new being, a new humanity, a new cosmos" (Pedersen, 2011, p. 45 cited in Larkin 2013, p. 333). Knox and Harvey, 2012, in their study of roads in northern Peru, make a similar argument but with a different approach-of how infrastructure is experienced by the local population. Roads, they argue, are closely tied to the local population's desire for connection and modernity. The idea is that roads are physical support system of a regional economy that initiates a process of economic advancement through closer integration with the state and global trade system (Knox and Harvey, 2012).

Nation-building exercises and infrastructure development are two closely tied projects of the state as manifested in the history of infrastructure development of Pakistan. In the 1950s emerged a distinct discourse in the global economic development circles focusing on development as infrastructure (Anwar, 2015, p. 8). This shift was crucial for the then Third World not only in concrete economic terms-in formulating financing arrangements and defining the trajectory of international aid-but also in 
how it affected state's role as a central planning authority. Infrastructure was placed at the center for the economic reconstruction of post-colonial societies like Pakistan. Pakistan was to develop using foreign financing and expertize from the World Bank and Ford Foundation. Foreign advisors and economists developed ideas that aided the development of the new discourse locally. "Their writings particularly signaled the intensely metonymic relationship between infrastructure and the state" (Anwar, 2015, p. 6). To overcome its backwardness, it not only had to have a disciplined, enterprising and productive population but it also needed national electricity grid, industries, automobiles, roads, and airports. Furthermore, infrastructure was also imagined as a binding force between the geographically odd East and West Pakistan (Anwar, 2015, p. 35-37).

The close relationship between infrastructure and state continued to exist throughout Pakistan's history. However, not always was this relationship as harmonious as the central state had wanted it to be. The central Pakistani state's attempts at creating an integrated space through infrastructural projects were met with alternative conceptions of nationhood of various regional elites.

Majed Akhter, in his analysis of the politics of Indus river infrastructure development, also notes a similar pattern of incomplete hegemonic project of state. He argues that nationbuilding, economic reconstruction efforts and provision of large dams and other river infrastructures have been closely tied together in the case of Pakistan (Akhter, 2015). Indus Water Treaty, signed on 19 September 1960, divided the control over Indus River and its tributaries among India and Pakistan. The Indus Basin Development Agreement signed on the same day secured Pakistan $\$ 895$ million as development grants from rich capitalist states for the construction of dams and other waterways. Apart from redirecting the use of water the projects also contributed to "the infrastructural production of state-space" (Akhter, 2015, p. 861). Availability of large development funds and creation of an integrated water network expanded the strength and spatial reach of the state. However, the central state's project of integrating national space was met with resistance from the regional intellectual elites (Akhter 2015, p. 860-861). The provincial politicians, who enjoyed important power positions in the bureaucracy, by virtue of the colonial legacy of "overdeveloped" state, remained unconvinced that the central state's nation-building process was an inclusive one. Such resistances intensified over time developing into regionalist ambitions. The case of secession of East Pakistan in 1971 revealed the strength of these forces (Akhter, 2015).

\section{The military-bureaucratic state of Pakistan}

To understand the roots of regionalism in Pakistan it is imperative to deconstruct the nature of Pakistani state. For this purpose, Hamza Alavi's article, "The state in post-colonial societies: Pakistan and Bangladesh" is particularly insightful (1972). He argues that the structure of Pakistani state cannot be fully understood without understanding the institutional legacy it inherited from the colonial state. The colonial government or the metropolitan bourgeoisie needs an elaborate state apparatus in order to exercise dominion over all the indigenous social classes in the colony. Resultantly, power devolves to the militarybureaucratic state apparatus created through this structure of governance. He termed such a state as an "overdeveloped" state. Pakistan inherited this structure of colonial governance (1972). Predominance of the military-bureaucratic state structure continued throughout the history of Pakistan. Pakistan did not have any well-developed political party organizations, which hampered the process of developing a functional parliamentary democracy
(Jalal, 1990). Hence, Pakistan has relied on its civil service and military to handle state functions. Concentration of power in the hands of such selected elite without a strong hegemonic project has created regional fissures (Jalal, 1990). The disproportionate representation of Punjabis in the military and civil bureaucracy further deepened these grievances. Desperate attempts by the state such as the One Unit ${ }^{7}$ could not do much to assuage the symptomatic conditions of these deep fissures. In the following sections, I present the case studies of Sindh and Balochistan to illustrate the roots of these grievances in the context of infrastructural development.

\section{Sindh and hydraulic regionalism}

Although, most of the tension between the provinces emerged from the Punjabi disproportionate presence in the bureaucratic and military structure of state, friction between Punjab and Sindh is also rooted in the technological appropriation of Indus river waters (Akhter, 2013). The fact that Punjab is upstream and Sindh is downstream creates a political geographic dynamic. This dynamic led to the creation of friction between the two provinces once the colonial state began its project of planned river control system (Akhter, 2013, p. 151). As more water began to be held by Punjab through various infrastructure technologies, Sindh's water rights got stifled. These tensions continued into independence. The Punjabi military-bureaucratic elite helped Punjab appropriate a greater share of Indus waters than was its due (Akhter, 2013).

Finally, the hydraulic projects of the central state also gave impetus to regionalist politics. Tarbela dam, one of the most important dams in the country, became a very contentious site as the provinces vied for rights over the water stored in the dam. While the provinces fought for greater water rights, Punjab argued that it needed a greater share in order to compensate for the loss to India of the three Eastern Rivers. The Committee setup to discuss the issues surrounding rights to storages at Tarbela constituted disproportionately of Punjabis; out of the 15 members, 11 were Punjabis. The final report of the committee favored the opinion that Punjab was entitled to greater allocation rights. Resultantly, the four members issued their notes of dissent, albeit with little consequence. Tarbela Dam was constructed and Punjab was given disproportionate share of stored water.

Although, all of the provinces got affected by the unfair character of the hydraulic technologies, Sindh and Punjab have been in direct confrontation by virtue of their upstream/downstream dynamic. Furthermore, Sindh is a largely agricultural province relying mostly on water from Indus. Unlike Punjab, Sindh doesn't have much useable groundwater and it receives much less rain than Punjab. Hence, the grievances were deeprooted and are yet to be resolved (Akhter, 2013).

\section{Baluchistan: Nationalist politics of underdevelopment and development}

Apart from Sindh, another province that has consistently opposed the central state's hegemonic project is Baluchistan. The history of nationalist sentiments among Baluchi elites can be traced as far back as the late colonial period. Creation of Pakistan was a heavy blow to the regional elites (particularly Baluch and Pashtun) hoping to create autonomous states based on their ethnicities (Titus and Swidler, 2000). At the time of independence, the tribal leaders and municipal authorities in British Baluchistan were given the option to choose between declaring Baluchistan an independent state or to join Pakistan. Although, these elites opted to join Pakistan, there were committed groups of activists that opposed the manner in which this decision was imposed. Actions against the project ranged from peaceful 
political organizing to sabotage. The nascent state, dominated by the Punjabi military-bureaucratic elite, responded with arrests and its own sabotage campaigns (Titus and Swidler, 2000). A focal point of early Baluch nationalism was the Kalat region (Atarodi, 2011). Soon after the creation of Pakistan, independence of Kalat was declared. However, the central state refused to accept the declaration and through military action, Kalat was forced to assimilate into Pakistan on 27 March 1948. From that day on, Baluch nationalism intensified overtime. The friction between the central state and Baluch activists continued throughout the history of Pakistan, gaining momentous during periods of insurgencies and military action in 1948, 1958, 1962, 1973, and 2004 (which marks the latest wave of insurgency). After the first military crackdown in 1948, the province was put under Governor-General Control. Baluchistan did not get any electoral representation in the state until 1972, when National Awami Party (the progressive political party that eventually led the movement for independent East Pakistan) gained sweeping victory in Baluchistan. The newly elected representatives began to demand for state rights, pointing to the relative underdevelopment of the state. However, with the discovery of natural gas, the province had become very important to Pakistani state and hence Bhutto ${ }^{8}$ refused to grant NAP its demands of greater autonomy. Bhutto dissolved the Baluchistan assembly and restored Governor's rule. This led to the prolonged series of military confrontations (Atarodi, 2011). By the time the fighting subsided in 1977, grievances had deepened and intense separatist feelings had penetrated widely (Harrison, 1981).

Although one of the major historical reasons contributing to Baluch insurgency has been the relative underdevelopment of the province, the recent wave of insurgency is mobilized around the very opposite issue (Aslam, 2011; Grare, 2006). It has been fueled by the massive development projects that the central government is undertaking in the province (Grare, 2006). Government of Pakistan, from the very beginning, has exploited the province by extracting the provincial resources without giving the Baluch their due share. Not only have the royalties for these resources been low, but the province has also benefited the least from them. Hence, the Baluch nationalists and militants, extremely skeptical of these interventions of central state, have mainly targeted Pakistani and foreign involvement in "development" projects in Baluchistan. The military operation carried out in 2005 appeared to be a result of Baluchistan Liberation Army's (BLA) rocket attack carried out a few hours before General Musharraf's visit there (Atarodi, 2011).

The huge land mass of the province, its reasonable endowment of natural deposits like gas, minerals, and its highly strategic coast means that it is feasible target central state's extractive ambitions (Akhtar, 2007). Given the long history of exploitation of the province, the nationalist elements have responded to state-led infrastructure projects with suspicions and outright rejection. Exploitation of gas reserves and acquisition of Gwadar port are the classic manifestation of state-led infrastructure projects being a site of resistance in Baluchistan (Akhtar, 2007).

Despite being a major producer of gas, Baluchistan not only receives much less share of gas than other provinces do, it also receives only $12.4 \%$ royalties of the gas produced in the province (Grare, 2006). This trend of exploitation has been fairly consistent over the years, building up grievances among the Baluch population. The result being that the Baluch nationalists are now violently opposing the exploitation of the gas reserves by central government (Grare, 2006). According to South Asia Terrorism Portal, there have been 165 incidents of attacks on gas pipelines from 2005 to 2011 (Mohanty, 2011).

Development of Gwadar Port is another locus of tension. In collaboration with China, the government of Pakistan started developing a deep sea port and ancillary infrastructure and industries at the coastal town of Gwadar on the Arabian Sea (Aslam, 2011). The Baluch nationalists assert that the agreement between the federal government and the Chinese company related to the development project is another proof of the exploitation of Baluch wealth. They claim that Pakistani state and the Chinese company are taking most of the profit from these projects, leaving little for the people of Baluchistan. To make matters worse, all construction contracts are given to non-Baluch firms (Aslam, 2011).

Furthermore, as Frédéric Grare points out, most of the people involved in the projects are from outside of Baluchistan (Grare, 2006). There is a growing fear among the Baluch youth nationalists that Gwadar is likely to continue to precipitate an influx of non-Balouch seeking employment (Akhtar, 2007). The fears are grounded in reality: out of 600 people employed in the first phase of construction of Gwadar port, only 100 were Baluch (Grare, 2006).

The case of Sindh and Baluchistan show that instead of integrating national space and creating a hegemonic state-space, politics of infrastructure have only created and deepened fissures in the national space. Regionalist ambitions have been exacerbated by the central state's attempts to create an integrated space through technologies of integration. In the following sections, I talk about how CPEC is interacting and is expected to interact with these features of the Pakistani political economy.

\section{CPEC and politics of regionalism}

Political and militant presence of nationalist forces, Islamic extremists (now including Islamic State), makes Baluchistan a very contentious and dangerous space for CPEC. Although Baluchistan has proved to be most difficult for the Pakistani and Chinese actors involved in CPEC, the regional problem of CPEC extends the boundaries of Baluchistan. Planning of CPEC has been highly centralist and provincial governments have not responded well to these tendencies. Chinese engagement (through CPEC projects) has so far only deepened these regional cleavages. The regionalist forces have opposed the project in two broad ways: through demanding greater share in the project or through completely rejecting the interventions.

The center-province friction has manifested itself through the CPEC route controversy. Provincial governments have objected to the change in route of the roads and railways projects. The government of Pakistan announced that the original route, or Western alignment, will start after the completion of eastern alignment. According to the original plan, the corridor-constituting highways and railways-was to connect Gwadar to Kashgar, passing through various southern and eastern districts of Baluchistan, some parts of South Punjab, Islamabad (beyond which there is no difference between the Eastern and Western route) (Abid and Ashfaq, 2015). However, fears (backed by statistical data) among the regional elites have started emerging that central political elite is giving priority to the eastern route (Mengal, 2016). The Eastern Route completely cuts through Baluchistan, connects Gwadar to Karachi through bypassing major districts in Baluchistan, and mostly passes through the relatively well-developed provinces of Punjab and Sindh (Mengal, 2016). Different claims have been made by the government since this controversy emerged (Bengali, 2015). Although the maps have not been disclosed and statements have been kept vague and confusing, what does emerge from the press releases is that the route has been changed to pass mostly through Central Punjab instead (Bengali, 2015).

Even though a parliamentary committee has been established, not enough consultation has been made with the provinces in 
Pakistan (Qureshi, 2015). Provincial Assembly of Khyber Pakhtunkhwa (KPK) rejected prioritization of Eastern route and passed resolution opposing any route change, since the original route holds the promise of benefitting the underdeveloped areas of KPK (Mengal, 2016; Ahmad and Hong, 2017). Aftab Ahmed Sherpao, leader of the Qaumi Watan Party-the party that emerged as the fourth largest party in KPK in the 2013 General Electionsexpressed his concerns about the national outreach of CPEC in a parliamentary committee meeting held in October 2016 (Raza, 2016). Claiming to represent all members of the opposition party, he claimed that government claims of injection of 10,000 megawatts of electricity into the national grid holds little promise for the provinces other than Punjab. Since all the other provinces have a weak power distribution system, the increase in the production of energy will not benefit these marginalized provinces (Raza, 2016).

Gilgit-Baltistan has also been demanding greater share in CPEC through protests and strikes (Ali, 2016). The central government responded by threats. Ministry of Planning, Development and Reforms announced that those protesting against CPEC will be charged under anti-terrorism laws (Business-Standard, 2016). The government has also responded to the objections raised by the provinces by repeatedly assuring that CPEC will benefit the provinces equally and through announcing projects in these provinces. Whether the central government will go through with these promises is uncertain and the lack of transparency is only going to stimulate these fears and opposition even further.

The trend in Baluchistan, due to history of exploitation in the province, has been the opposite. They have opposed CPEC on the grounds that it will further strengthen the circle of exploitation emerging from the center-this time in collaboration with a foreign state (Ahmad and Hong, 2017; Mengal, 2016). The Baluch separatists and militants have shown their opposition to CPEC by carrying out various acts of sabotage such as, target killing and abduction of Chinese workers and blasts targeting CPEC project sites or infrastructure.

Consequently, despite the promises of connectivity, integration, and development of entire nation, CPEC has mobilized a new wave of regional politics. The route controversy reveals the centralizing - not inclusive-mission of state. Provinces have not only been kept in dark regarding the planning process, but state has also responded inadequately to the fears of provinces and in some cases has even threatened repression. Assuaging nationalist sentiments in Baluchistan through CPEC has remained an elusive project of Pakistani state. Hence, not much can be expected from CPEC in terms of nation-building unless it is backed by a strong material and ideological project of uniting the provinces. Central state, which is bent to pursue its own interests, has not shown much commitment to this end.

However, the political boundaries of CPEC extend beyond the national territory-Chinese state and international organizations will play a crucial in the CPEC process. How can we logically expect the Chinese state to respond? The answer to this question needs to be grounded in China's foreign policy and Chinese interests in Pakistan.

\section{Chinese capital and "non-interference"}

Perhaps the most salient feature of Chinese capital that has been readily advertised as the revolutionary principle that marks the new global order is that of non-interference and peaceful coexistence. Furthermore, the core purpose of the National Security Commission of China is to engage in dialog and negotiations on an equal footing to overcome disputes and make peace possible. China envisions a "fair and reasonable new international order" to guarantee peace and security (Shambaugh, 2013, p. 79).
Overtime, due to certain geopolitical events and circumstances, China has become less passive and more proactive globally-it has stepped-up participation in regional organizations, established many bilateral relations, and has become more engaged in multilateral organizations (although still reluctant to exercise coercion to make a regime submit to international norms and rules on issues such as climate change, military transparency, human rights, and to a certain extent, counter terrorism).

China's interest in security, political stability, and reluctance to engage in contentious politics abroad are partly attributable to China's long history of internal and external insecurity and paranoia (Shambaugh, 2013). The persistent internal threats of secessionist movements have pushed China to enter into coalitions of anti-secessionist movements, the consequences of which transcend the national boundaries (Karatasli and Kumral, 2017). These anti-secessionist sentiments and external security threats combined with the economic interests of China, "seem to push China to preserve the global status quo in a very consistent manner" (Karatasli and Kumral, 2017, p. 22). Among several others, Karatasli and Kumral cite the example of issues surrounding South Sudan and Chinese role amidst the direct actions of international powers and multilateral organizations. As secessionist movement in South Sudan gained power, China's tensions grew. South Sudan was becoming an important site for serving Chinese economic interests. By 2001, South Sudan attracted international prominence-secession and human rights problems found strong Western coalition support. Till the very end, China tried to keep Sudan united playing the role of a mediator. When in 2011, South Sudan gained independence; China put efforts into building trade relationships with South Sudan as well (Karatasli and Kumral, 2017, p. 22-23).

However, exemplified by the case of Namibia, there have been exceptions to China's policy of non-intervention and lack of support for independence movements. Beijing extended its support to the Black Nationalist liberation movement against apartheid and white domination of South Africa (Larmer, 2017). China became one of its first allies when in early 1990 Namibia claimed independence. This move on Beijing's part needs to be contextualized in China's need to look for allies after its diplomatic isolation following the crackdown of Chinese government on the Tiananmen Square protestors in 1989 (Larmer, 2017, p. 4).

The above discussion illustrates how China is bent upon preserving political stability and is completely intolerant to regionalist ambitions given the problem of regionalism within its borders. Hence, it is safe to expect here that China will also not react well to the regional elites making diverging claims to the central planning of CPEC. China will not tolerate giving concessions or autonomy to the regionalist elements lest it gives confidence to the regionalists in its own boundaries.

\section{CPEC and security}

Over the years, Pakistani military's penetration into politics, society and economy has accrued the military establishment an important position in the state apparatus. Real and imagined security threats besetting Pakistani state, role of foreign powers and the ever-growing financial autonomy of the defense establishment have led to the creation of a crisis-ridden, "garrison" state of Pakistan. To make matters worse, an increasingly powerful role has been assumed by Pakistani military during the lifespan of CPEC. The army has pushed for a formal role in the execution of the projects. Pressure from Pakistani army and Beijing's disappointed over the performance of federal government in securing a stable environment for CPEC development has meant that army has made important headways in acquiring an important role in CPEC. The rhetoric of security has also been 
used to justify lack of transparency, censorship, and arbitrary actions of the state, making the process of planning and execution of CPEC highly undemocratic.

On the eve of independence, Pakistan inherited an elaborate military structure. The colonial rule in India was mediated through a garrison state. British powers were fully aware of the effective role that force and coercion played in ruling India (Ahmed, 2013). Writing about the militaristic nature of Punjab, Tan Tai Yong remarks that the colonial legacy of militarization of Punjab can be crucial in explaining the post-colonial state of Pakistan (Ahmed, 2013, p. 13). He argues that the rise of militarybureaucratic oligarchy heavily dominated by Punjabis, which was powerful enough to dominate and control the state apparatus of Pakistan is to be partially explained by the developments in colonial Punjab in the early twentieth century (Ahmed, 2013).

The colonizers through their recruitment policy created the myth of "martial race" of Punjabis (Siddiqa, 2007). After the mutiny of Bengal Army in 1857, British rulers were faced with the need to restructure the armed forces. At this juncture, the colonizers found that Punjabis were more willing to enlist in the British army in return for employment opportunities and material rewards. As a result, the number of Punjabis in the British army grew disproportionately (Siddiqa, 2007).

The myth of Punjabis and Pathans (from North-West Frontier Province) as "martial race" continued even after independence. This acted as a cohesive force for retaining ethnic composition and maintaining the inherently elitist fabric of military (Siddiqa, 2007). Furthermore, the colonial bias against Bengalis, Sindhis, and Baluchis in recruitment processes continued. This discriminatory policy fed the tension between the center and the provinces. Consequences have been dire: Baluch leaders uphold grievances against the military who view it not as a national military but a Punjabi force that exploits (Siddiqa 2007: p. 60).

The strong military apparatus bequeathed by the colonial government acquired more power as the nascent state struggled with nation-making. Owing to the deep sense of insecurity that ensued after independence, the army attained a central role as a protective authority (Ahmed, 2013). The ideology on which Pakistan's nationalist struggle was based had a huge role to play in creating these threats. The independence struggle was pitched as a struggle for a separate homeland for Muslims. The much celebrated "Two Nation Theory", ${ }^{10}$ for once and for all, discarded all commonalities between Muslims and Hindus of India. The bloody riots following the partition of the subcontinent and an exaggerated belief that India was intent on leading Pakistan to ruin set the stage for national obsession with security (Ahmed, 2013). The imagined fear took shape following the multiple wars between India and Pakistan over the Kashmir issue (Siddiqa, 2007: p. 63). The conflict holds immense priority among policy makers and the military establishment, who perceive Indian threat as the primary threat to Pakistan. Even internal threats such as Baluch insurgency and other ethnic and religious tensions are perceived as an extension of this external threat (Siddiqa, 2007).

The military establishment derived its ideological power from the Indian threat and economic strength from foreign powers. Due to certain strategic events, development aid was quickly turned into military aid (Ahmed, 2013). The bipolar rivalry between the United States and former Soviet Union gave the ruling elites a very effective strategic advantage to solicit alliance with the US (Ahmed, 2013). The civil and military rulers of Pakistan utilized this opportunity by marketing Pakistan as a frontline state against the rise of communism and communist powers. When the alliance with the US to contain the spread of communism became more or less dormant in the 1960s, Pakistan sought alliance with China. Later, Pakistan further diversified this web of dependence by seeking support of Saudi Arabia. The Pakistan-US alliance refurbished with the Soviet occupation of Afghanistan and Iranian Revolution. China has also similar concerns against the Soviet occupation. Saudi Arabia felt threatened by the rising power of Iranian strand of Islam. All these powers could realize their objectives through Pakistan. The Pakistani military exploited this unique strategic position of Pakistan to serve its interests (Ahmed, 2013).

Given the vested interests of foreign and local powers in militarizing the state, it is no surprise that over the 67 years of independence, the military establishment acquired enough power to rule the country four times. Even during times of civilian rule, army has maintained considerable power by negotiating authority (Siddiqa, 2007). Five armed conflicts with India, several operations in Baluchistan to suppress the organized demands for greater autonomy, and the most recent "war against terrorism" not only indicates the level of militarization of state but is also symptomatic of formidable power in the hands of Pakistan army (Siddiqa, 2007).

\section{Pakistani military and CPEC}

An increasingly powerful role has been assumed by the military during the lifespan of CPEC. Army has pushed for a formal role in the execution of the projects and proposed incorporation of CPEC in the National Action Plan ${ }^{11}$ (Rana, 2016). The latter proposal was rejected by the civilian set-up and the civilian government has been overall reluctant in sharing control over CPEC (Ghumman, 2016). However, army's power to meddle with civilian politics combined with Beijing's disappointed over the performance of federal government in securing a stable environment for CPEC development (Ghumman, 2016) has meant that army has made important headways in acquiring an important role in CPEC.

The power that Pakistani army is gaining in CPEC operations is making the process of CPEC highly undemocratic. It is leading to further weakening of the civilian government. There are several developments that point towards this trend. Firstly, new armed forces have been formed in Baluchistan and Sindh by the army, dedicated solely to protect the CPEC projects (Wolf, 2016). This decision was made solely by the top officials of the army (Wolf, 2016). According to the four-layer security plan, an estimated 32,000 security personnel have been assigned to guard over 14,321 Chinese workers engaged in various projects throughout the country (Gishkori, 2015). According to the plan, Baluchistan will be guarded the heaviest, getting about 5,700 personnel of the Frontier Corps. ${ }^{12}$ Similarly, the operation Zarb-e-Azb launched by the army to control militancy in North Waziristan in 2014 also gained legitimacy through CPEC. The Chinese foreign policy makers were satisfied by the Pakistani army's attempt to eliminate the insurgency led by the East Turkestan Islamic Movement in the region. Likewise, the Chief of Army Staff kept reiterating the operation's contribution to ensuring a secure environment for the completion and management of CPEC.

Secondly, the establishment of Apex committees at federal and provincial levels aimed at enhancing communication between civilian and military powers regarding security matters had the effect of further weakening the decision-making powers of the civilian government (Wolf, 2016). Handling powers to the apex committees has meant that important decisions regarding CPEC are now being made by the military-bureaucratic complex without any participation by the national or provincial assemblies (Wolf, 2016).

The military by invoking the rhetoric of security concerns has exonerated the state from making CPEC transparent and open to 
public debate. Lack of transparency, censorship, and arbitrary actions of the state are conveniently justified by labelling CPEC as a matter of state security (Ali, 2017; Bengali, 2015). If the situation persists, the planning and implementation of CPEC will become highly undemocratic, creating deeper fissures in the state space. However, this potential needs to be evaluated considering not just the politics of Pakistani state and society but also the nature of the investment regime of CPEC, the Chinese state, and international actors. Although, as mentioned earlier, the official rhetoric of China's global investment policy is that of 'noninterference', the foreign policy seems to be evolving as China realizes the limitations of non-interference and the importance of protecting its economic interests (Mohan and Power, 2010). For example, the policy of blocking UN Security Council resolutions authorizing peacekeepers for Darfur has been lifted and China has put modest pressure on Khartoun to allow UN peacekeeping deployment (Hansen, 2008). Changes in the Chinese foreign policy are driven by the need to secure business interests and concerns about "a backlash and the potential damage to its strategic and economic relationships with the United States and Europe" (Ahlbrandt and Small, 2008). However, this emerging shift is to be understood cautiously as China has not experienced a fundamental change in values. Economic interests remain the top priority and, despite its increasing involvement with the US, China does not share their rhetoric of human rights and democracy (Ahlbrandt and Small, 2008).

Although China's foreign policy has shown flexibility, it is important to note that Chinese presence in the Global South is driven by certain national and economic interests. China has shown willingness to forgo its non-interference stance if its economic and national interests necessitate it. In Pakistan, China showed this flexibility by pushing for the security establishment's takeover of the security issue of CPEC. Involving the Pakistani military was also in China's national interests. Fighting Uighur militants in North Waziristan was one of China's crucial concerns that led to the Chinese state forming an alliance with Pakistani military. Historically as well, China has been more comfortable in negotiating with Pakistani military elite than its turbulent civilian counterpart (Small, 2015). Hence, Pakistani military elite's power can only be expected to strengthen with this project unless there's a serious international or local resistance to this trend.

\section{Conclusion}

The study aimed to understand how CPEC is interacting with the political economic structure of Pakistan. To this end, through a historical analysis, I deconstructed the Pakistani state and divided it into three major powers: the central state, the regional elites, and the military. Throughout the paper I used these categories to analyse the role of these powers in the planning and implementation process of CPEC and how these interactions are affecting the political landscape of Pakistan. Furthermore, I outlined the economic, national and strategic interests of China in Pakistan in order to analyse how China can be expected to intervene in this process.

After establishing a link between infrastructure and state, I argued that, since the very beginning, the project of infrastructure development in Pakistan has been deeply connected with the nation-building process. However, in its attempt to create a homogenous space, the Punjabi-dominated central state ended up creating fractured spaces that housed regionalist ambitions. CPEC, I argued, has initiated a new regime of regionalist politics by appropriating a disproportionate share of projects to Punjab and by keeping the planning of CPEC highly secretive and undemocratic.
Next, I analysed the role of military in Pakistani politics to understand its role in CPEC. Over the years, Pakistani military's penetration into politics, society and economy has accrued the military establishment an important position in the state apparatus. $\mathrm{CPEC}$ has become another opportunity for the military to expand its influence in the decision-making process of the state. The Army has pushed for a formal role in the execution of CPEC projects. The process has been facilitated by Beijing's security concerns and its own war against Uighur militants. The rhetoric of security has also been used to justify lack of transparency, censorship, and arbitrary actions of the state, making the process of planning and execution of CPEC highly undemocratic and unequal. Hence, I conclude that unless there is a serious international or local challenge to this trend, CPEC will only lead to an increase in the power of Pakistani military.

An analysis of the China's foreign policy and national interests led to the conclusion that China has little interests or motivation to alter the power imbalances in Pakistan that are being exacerbated by CPEC. China is intent on preserving political stability in its bilateral relations. This inclination is reflected by a no stringsattached aid policy, reluctance to meddle in the internal issues, and respect for territorial sovereignty. The less apparent driver of China's foreign policy is its national interests, which sometimes diverge from its principles of non-intervention. For example, China is bent upon preserving political stability and is completely intolerant to regionalist ambitions given the problem of regionalism within its borders. Given this concern, China is expected to not react well to the regional elites, making diverging claims to the central planning of CPEC.

Hence, I argue that, unless there is national or international backlash against the effects of CPEC on Pakistan's political economic structure, CPEC can be expected to maintain the status quo of power structures of the Pakistani state-the fissures of which are going to only deepen further.

Received: 26 April 2017 Accepted: 23 April 2018

Published online: 05 June 2018

\section{Notes}

1 Pakistan Muslim League $(\mathrm{N})$ is a center-right conservative party in Pakistan. PML-N is claimed to be solely representative of Punjabi interests.

2 Although there is no available data on the number of CPEC-related terrorist activities that have occurred in the past, there are some news reports that paint the bloody picture of CPEC. A report by a Pakistani, English language newspaper, "The Nation" claimed that different attacks have killed 44 Pakistani CPEC-related workers between 2014 and 2016. The targets were mainly men working on the construction of road in Balochistan (The Nation, 2016). In a report compiled by Asia Times in 2017, several incidents of different nature have been recorded occurring in Balochistan and Sindh that year. The report lists incidents targeting Frontier Corps personnel, police officers, CPEC laborers, and Chinese nationals working for different CPEC related projects (Shakil, 2017). Although the security situation surrounding CPEC is dire and demands attention, various acts of violence are also being used by various stakeholders to support the narrative that CPEC is under threat from external powers. Attacks and blasts in Balochistan have been openly labeled as "attempts to sabotage CPEC" by government officials (Shahid, 2016).

3 Turkistan Islamic Party is an extremist Islamist party founded by Uyghur nationalists in Western China. The separatist party aims to form an independent state for Uyghurs in Xinjiang called "East Turkestan" (Davis, 2010).

4 Uyghur Muslims are a religious and ethnic minority in Xinjiang province of China Under the Qing state, Xinjiang region was never colonized and was strategically maintained as a frontier zone with its own governing structure (Davis, 2010). After the fall of Qing dynasty and the ensuing political turmoil, China was declared a multinational state in 1949. However, The Communist Party's anti-rightist campaign aimed to root out "local nationalism." The Cultural Revolution was an even stronger force against the ethnic minorities inhabiting in China. The Uyghur in Xinjiang were one of the victims of this state repression. Over the years, this ethnic minority developed into a separatist, militant entity (Davis, 2010). The Uyghur militants are 
believed to have transnational networks in Afghanistan, Pakistan, Tajikistan, Kyrgyzstan, and Kazakhstan (Davis, 2010; Small, 2015).

5 The civilians have become victims of War on Terror (Qazi, 2012). Apart from the budget restraint caused by massive military spending, civilians have also been direct targets of the war. CIA's drone campaign inside Pakistan started in 2004. Although, the strikes target the al-Qaeda operatives, civilian deaths have been too colossal to go unnoticed. Both Pakistani and US public have criticized and opposed the drone strikes, seriously undermining the popularity of US-Pakistan relations. Although the military and civilian governments of Pakistan have openly condemned the strikes, they have supported the strikes behind the scenes. However, given the growing unpopularity, the government has recently tried to push for greater role in decisionmaking over the strikes (Qazi, 2012). Yet, despite growing criticism against drone warfare, it remains a vital component of US' war against terrorism (Williams, 2017). By October 2015, number of drone strikes sanctioned by the Obama administration had risen up to 353 (compared to 48 drone strikes under President Bush) (Williams, 2017).

6 Goswami argued that part from being the symbolic representation of socioeconomic progress giving legitimacy to the colonial state; infrastructure also became the center of initiating new forms of subjectivity (Anwar, 2015, p. 31). Infrastructure would irreversibly make the populace subjects of the state and parcel out sets of rights and duties to them. Infrastructure, in other words, would discipline and civilize the populace. Infrastructure also became a locus of patron-client relationship; of distributing out benefits to the loyal supporters, creating preferred subjects of the state (Anwar 2015, p. 31).

7 One Unit was an administrative reform enacted in West Pakistan in 1954 that merged all the provinces into a single structure. Spearheaded by the bureaucraticmilitary elite, the reform was partly passed to suppress regionalist politics that were recently gaining momentum.

8 The fourth president of Pakistan from 1971 to 1973.

9 The term was originally coined by Tan Tai Yong in his book "The Garrison State: Military, Government and Society in Colonial Punjab, 1849-1947" to describe the colonial state structure in Punjab. However, it has been later used by authors like Ishtiaq Ahmed to describe the Pakistani state.

10 The Two-Nation Theory was an ideological tool used to mobilize Muslims for the Pakistan Movement positing that religion is primary identity of the South Asian Muslims and rather than language or ethnicity, their Islamic identity is the unifying denominator. Implicitly and extremely effectively, the ideology projected Hindus and Muslims of South Asia as being so different that they could not live together in one nation, even though the history of South Asia is precisely that of coexistence of Hindus and Muslims.

11 Pakistan's counter-terrorism policy adopted in 2014

12 Frontier Corps is a security force part of the paramilitary forces of Pakistan stationed in Baluchistan and KPK. Although the force falls under the jurisdiction of the Interior Ministry, it is headed by a major-general rank Pakistan army officer.

\section{References}

Abid M, Ashfaq A (2015) CPEC: Challenges and opportunities for Pakistan Pakistan Vis 16(2):142-169

Ahlbrandt S, Small A (2008) China's new dictatorship diplomacy. The New York Times, [online]. Available at: http://www.nytimes.com/cfr/world/ 20080101faessay_v87n1_kleine.html?pagewanted=print\&_r $=0$

Ahmad R, Hong M (2017) China-Pakistan economic corridor and its social implication on Pakistan: How will CPEC boost Pakistan's infrastructures and overcome the challenges? Art Soc Sci J, 08(02)

Ahmed I (2013) The Pakistan garrison state origins, evolution, consequences (1947-2011). Oxford Univ. Press, New York

Akhtar AS (2007) Balochistan versus Pakistan. Econ Polit Wkly 42(45):73-79

Akhter M (2013) The geopolitics of dam design on the Indus. Econ Polit Wkly 48 (19):24-26

Akhter M (2015) Infrastructure nation: State space, hegemony, and hydraulic regionalism in Pakistan. Antipode 47(4):849-870

Alavi H (1972) The state in post-colonial societies: Pakistan and Bangladesh. New Left Review, I/74 [online]. Available at: https://newleftreview.org/I/74/hamzaalavi-the-state-in-post-colonial-societies-pakistan-and-bangladesh

Ali A (2016) China Pakistan economic corridor: Prospects and challenges for regional integration. Art Soc Sci J, 7(4)

Ali U (2017) Pakistan's Censorship Takes a Dangerous Turn. The Diplomat. [online]. Available at: http://thediplomat.com/2017/02/pakistans-censorshiptakes-a-dangerous-turn/

Anwar NH (2015) Infrastructure redux: Crisis, progress in industrial Pakistan and beyond. Palgrave Macmillan, London

Aslam R (2011) Greed, creed, and governance in civil conflicts: a case study of Balochistan. Contemp South Asia 19(2):189-203

Atarodi A (2011) Insurgency in Balochistan and why it is of strategic importance. Defense Analysis. FOI, Stockholm, pp. 2011
Bengali K (2015) China-Pakistan economic corridor-The route controversy. Chief minister's policy reform unit-Government of Balochistan. Karachi: The Times Press

Business-standard.com (2017) Protestors to be charged under anti-terrorism laws: Pak on CPEC row. Business Standard, [online]. Available at: http://www. business-standard.com/article/international/protestors-to-be-charged-underanti-terrorism-laws-pak-on-cpec-row-116081800623_1.html [Accessed 11 Jun. 2017]

Chandra D (2016) China-Pakistan relations: Implications for India, 1st edn. Vij Books India Private Limited, New Delhi

Cooley J (2001) Unholy wars: Afghanistan, America and International Terrorism. 1st edn. Pluto Press: London

Cpec.gov.pk (2017) China Pakistan economic corridor introduction [online]. Available at: http://cpec.gov.pk/introduction/1

Dalakoglou D (2010) The road: An ethnography of the Albanian-Greek crossborder Motorway. America Ethnologist, 37(1)

Elizabeth Van Wie Davis (2010) Uyghur Muslim Ethnic Separatism in Xinjiang, China, Asian Affairs: An American Review. 35(1):15-30. https://doi.org/ 10.3200/AAFS.35.1.15-30

Ghumman K (2016) PML-N unwilling to share CPEC control? Dawn, [online] Available at: https://www.dawn.com/news/1271483

Goswami M (2004) Producing India: From colonial economy to national space. University of Chicago Press, Chicago

Grare F (2006) Pakistan: The resurgence of Baloch nationalism. Carnegie Papers Massachusetts Avenue, NW: Carnegie Endowment for International Peace: $1-15$

Guldi J (2012) Roads to power: Britain invents the infrastructure state. Harvard, Cambridge

Hansen S (2008) China, Africa, and Oil. Washington Post [online]. Available at: http://www.washingtonpost.com/wp-dyn/content/article/2008/06/09/ AR2008060900714.html

Harrison S (1981) In Afghanistan's shadow: Baluch nationalism and soviet temptations. Foreign Aff 60(1):216

Hilali AZ (2002) The costs and benefits of the Afghan War for Pakistan. Contemporary South. Asia 11:291-310

Jalal A (1990) The state of martial rule: Pakistan's political economy of defence. Cambridge University Press, Cambridge

Karatasli S, Kumral S (2017) Territorial contradictions of the rise of China: Geopolitics, nationalism and hegemony in comparative-historical perspective. World-Syst Res 23:5-35. http://jwsr.pitt.edu/ojs/index.php/jwsr/article/view/ 591. Accessed 11 Jun 2017

Khan MA and Ahmed A (2007) Pakistan Institute of Development Economics, Islamabad Foreign Aid-Blessing or Curse: Evidence from Pakistan. The Pakistan Development Review, Vol. 46, No. 3 (Autumn 2007), pp. 215-240 Published by: Pakistan Institute of Development Economics, Islamabad Stable URL: http://www.jstor.org/stable/41261157 Accessed: 17-04-2017 10:34 UTC

Knox H, Harvey P (2012) The enchantments of infrastructure. Mobilities, vol. 7, No. 4, pp. 521-536, (November 2012)

Knox H, Harvey P (2015) Roads an anthropology of infrastructure and expertise. Cornell University Press, Ithaca, NY.

Larmer B (2017) Is China the world's new colonial power? New York Times Magazine, [online]. Available at: https://nyti.ms/2qsVH2B

Larkin B (2013) The politics and poetics of infrastructure. Annu Rev Anthropol 42:327-343. www.annualreviews.org

Lefebvre H (2009) Space and the state. In: Brenner N, Elden S (eds) State, space, world: Selected essays. University of Minnesota Press, Minneapolis, pp. $223-253$

Marx K (1857-61). Grundrisse: Foundations of the Critique of Political Economy. Penguin Books in association with New Left Review, [online]. Available at: https://www.marxists.org/archive/marx/works/1857/grundrisse/index.htm

Mengal S (2016) CPEC Route Controversy: Problems and Opportunities. BiAnnual research journal "BALOCHISTAN REVIEW" ISSN 1810-2174 Balochistan Study Centre, University of Balochistan, Quetta (Pakistan) vol XXXV, no. 2

Mohanty R (2011) Balochistan: Running out of Gas. South Asia Intelligence Review (SAIR), vol. No. 9.46, [online]. Available at: http://www.satp.org/satporgtp/ sair/Archives/sair9/9 46.htm. Accessed 11 Jun 2017

Naviwala N (2017) Playing hardball with aid to Pakistan. Foreign policy-South Asia Channel, [online]. Available at: http://foreignpolicy.com/2015/09/04/ playing-hardball-with-aid-to-pakistan/

'The Nation' (2016) Attacks have killed 44 Pakistanis working on CPEC since 2014 The Nation. Available at: https://nation.com.pk/09-Sep-2016/attacks-havekilled-44-pakistanis-working-on-cpec-since-2014

Pant HV (2012) The Pakistan thorn in China-India-U.S. relations. Wash Q 35 (1):83-95, [online]. Available at: htps://doi.org/10.1080/ 0163660 X 2012.642294 
Pedersen MA. 2011. Not Quite Shamans: Spirit Worlds and Political Lives in Northern Mongolia. Cornell Univ. Press, Ithaca, NY

Power M, Mohan G (2010) Towards a critical geopolitics of China's engagement with African development Geopolitics 15(3):462-495

Qazi SH (2012) US-PAKISTAN RELATIONS: Common and clashing interests. World Aff 175:71-78

Qureshi AH (2015) China/Pakistan economic corridor: A critical national and international law policy based perspective. Chin J Int Law 14(4):777-799. http://chinesejil.oxfordjournals.org/

Rana S (2016) Army seeks role in CPEC administration. The Express Tribune, [online]. Available at: https://tribune.com.pk/story/1085784/for-timelycompletion-army-seeks-role-in-cpec-administration/

Raza M (2016) Coal plant project likely to be shifted after govt-Kapco disagreement. Dawn, [online]. Available at: https://www.dawn.com/news/1245764/ coal-plant-project-likely-to-be-shifted-after-govt-kapco-disagreement

Shahid U (2016) Balochistan: The troubled heart of the CPEC. The Diplomat. Available at: https://thediplomat.com/2016/08/balochistan-the-troubled-heartof-the-cpec/

Shakil FM (2017) Catalogue of attacks shadows China's CPEC hopes in Pakistan. Asia Times. Available at: http://www.atimes.com/article/catalogue-attacksshadows-chinas-cpec-hopes-pakistan/

Shambaugh DL (2013) China goes global: the partial power. Oxford University Press, New York

Siddiqa A (2007) Military Inc. Inside Pakistan's Military Economy. Oxford Univ. Press, London

Siddiqui S (2017) CPEC investment pushed from $\$ 55 \mathrm{~b}$ to $\$ 62 \mathrm{~b}$. The Express Tribune, [online]. Available at: https://tribune.com.pk/story/1381733/cpecinvestment-pushed-55b-62b/

Small A (2015) China-Pakistan axis: Asia's new geopolitics. Oxford University Press, New York

Tareen SA (2016) Begum Nasim Wali warns against politicizing CPEC. The News [online]. Available at: https://www.thenews.com.pk/print/125687-BegumNasim-Wali-warns-against-politicising-CPEC

Titus P, Swidler N (2000) Knights, not pawns: Ethno-nationalism and regional dynamics in post-colonial Balochistan. Int J Middle East Stud 32:47-69

Washbrook (1981) Law, state and Agrarian society in colonial India. Modern Asian studies, vol 15, no. 3, Power, profit and politics: Essays on imperialism, nationalism and change in twentieth-century India. Cambridge University Press Stable, pp.649-721 URL: http://www.jstor.org/stable/312295

Williams B (2017). Counter jihad: America's Military Experience in Afghanistan. 1st ed. University of Pennsylvania Press, Philadelphia.

Wolf SO (2016) The China-Pakistan economic corridor and civil-military relations in Pakistan. IndraStra Glob 2(4):0052, http://www.indrastra.com/2016/04/PAPERCPEC-and-Civil-Military-Relations-in-Pakistan-002-04-2016-0052.html
Zaidi SA (2011) Who Benefits from US Aid to Pakistan? Economic and Political Weekly, Vol. 46, No. 32 (AUGUST 6-12, 2011): 103-109

\section{Data availability}

The datasets generated during and/or analyzed during the current study are not publicly available to maintain the confidentiality of the interviewees but are available from the corresponding author on reasonable request.

\section{Acknowledgements}

I would like to thank Dr. Burak Gürel for his supervision and support throughout this research. I would also like to acknowledge Dr. Erdem Yörük and Mustafa Yağc1 for their comments on the thesis from which this paper was derived. Mr. Muhammad Aqeel Awan's help in formulating this paper was also invaluable. I also feel deeply indebted to the Graduate School of Social Sciences and Humanities of Koç University for providing me with the opportunity and resources for conducting this research.

\section{Additional information}

Competing interests: The author declares no competing interests.

Reprints and permission information is available online at http://www.nature.com/ reprints

Publisher's note: Springer Nature remains neutral with regard to jurisdictional claims in published maps and institutional affiliations.

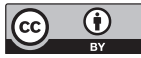

Open Access This article is licensed under a Creative Commons Attribution 4.0 International License, which permits use, sharing, adaptation, distribution and reproduction in any medium or format, as long as you give appropriate credit to the original author(s) and the source, provide a link to the Creative Commons license, and indicate if changes were made. The images or other third party material in this article are included in the article's Creative Commons license, unless indicated otherwise in a credit line to the material. If material is not included in the article's Creative Commons license and your intended use is not permitted by statutory regulation or exceeds the permitted use, you will need to obtain permission directly from the copyright holder. To view a copy of this license, visit http://creativecommons.org/ licenses/by/4.0/

(c) The Author(s) 2018 